\title{
Chemical Composition and Cytotoxic Activity of the Essential Oil and Oleoresins of In Vitro Micropropagated Ansellia africana Lindl: A Vulnerable Medicinal Orchid of Africa
}

\author{
Md. Moshfekus Saleh-E-In + ${ }^{+}$, Paromik Bhattacharyya and Johannes Van Staden *
}

\section{check for}

updates

Citation: Saleh-E-In, M.M.; Bhattacharyya, P.; Van Staden, J. Chemical Composition and Cytotoxic Activity of the Essential Oil and Oleoresins of In Vitro Micropropagated Ansellia africana Lindl: A Vulnerable Medicinal Orchid of Africa. Molecules 2021, 26, 4556 https://doi.org/10.3390/

molecules26154556

Academic Editor: Ricardo Calhelha

Received: 14 June 2021

Accepted: 20 July 2021

Published: 28 July 2021

Publisher's Note: MDPI stays neutral with regard to jurisdictional claims in published maps and institutional affiliations.

Copyright: (c) 2021 by the authors. Licensee MDPI, Basel, Switzerland. This article is an open access article distributed under the terms and conditions of the Creative Commons Attribution (CC BY) license (https:// creativecommons.org/licenses/by/ $4.0 /)$
Research Centre for Plant Growth and Development, School of Life Sciences, University of KwaZulu-Natal Pietermaritzburg, Private Bag X01, Scottsville 3209, South Africa; saleheinm@kangwon.ac.kr (M.M.S.-E.-I.); paromik600@gmail.com (P.B.)

* Correspondence: rcpgd@ukzn.ac.za; Tel.: +27-33-260-5130

† Present affiliation: Department of Forest Resources, Kangwon National University, Chuncheon 200-701, Korea.

Abstract: Orchids are rich treasure troves of various important phytomolecules. Among the various medicinal orchids, Ansellia africana stands out prominently in the preparing of various herbal medicines due to its high therapeutic importance. The nodal explants of $A$. africana were sampled from asymbiotically germinated seedlings on basal Murashige and Skoog (MS) medium and were micropropagated in MS medium supplemented with $3 \%$ sucrose and $10 \mu \mathrm{M}$ meta topolin $(m \mathrm{~T})+5 \mu \mathrm{M}$ naphthalene acetic acid (NAA) $+15 \mu \mathrm{M}$ indole butyric acid (IBA) $+30 \mu \mathrm{M}$ phloroglucinol (PG). In the present study, the essential oil was extracted by hydrodistillation and the oleoresins by the solvent extraction method from the micropropagated A. africana. The essential oil and the oleoresins were analysed by Gas Chromatography (GC) and GC/MS (Mass spectrometry). A total of 84 compounds were identified. The most predominant components among them were linoleic acid (18.42\%), $l$ ascorbyl 2,6-dipalmitate (11.50\%), linolenic acid (10.98\%) and $p$-cresol (9.99\%) in the essential oil; and eicosane $(26.34 \%)$, n-butyl acetate $(21.13 \%)$, heptadecane $(16.48 \%)$ and 2-pentanone, 4-hydroxy4-methyl (11.13\%) were detected in the acetone extract; heptadecane $(9.40 \%)$, heneicosane $(9.45 \%)$, eicosane $(6.40 \%)$, n-butyl acetate $(14.34 \%)$ and styrene $(22.20 \%)$ were identified and quantified in the ethyl acetate extract. The cytotoxic activity of essential oil and oleoresins of micropropagated $A$. africana was evaluated by MTT (3-(4,5-dimethylthiazol-2-yl)-2,5-diphenyltetrazolium Bromide) assay on Vero cells compared to the standard drug doxorubicin chloride. The present research contains primary information about the therapeutic utility of the essential oil and oleoresins of $A$. africana with a promising future research potential of qualitative and quantitative improvement through synchronised use of biotechnological techniques.

Keywords: Ansellia africana; cytotoxic; essential oil; micropropagation; oleoresins; orchid; MTT; Vero cells

\section{Introduction}

Medicinal herbs are rich treasure troves of many bioactive compounds which provide important remedies for chronic disorders and ailments [1,2]. With a special focus on Africa, the Traditional African Pharmacopeia provides cheap and economic bio-remedies to large African populations who are economically struggling to survive [3,4]. Among the herbal remedies used in various pharmacopoeias globally, orchids occupy a prominent position due to their various medicinal values in alternative treatment options [5]. Despite the fact that orchids have a huge reservoir of bioactive molecules, many of them are yet to be explored for various pharmaceutical applications; for example, Dendrobium chrysotoxum, Bulbophyllum kwangtungense, Dendrobium macraei and Cypripedium parviflora. The pharmacological potentials of orchids were evaluated in other countries, but very few studies have been reported on orchid species in South Africa. 
Ansellia africana, popularly known as "Leopard Orchid" is one such species which is highly prized globally because of its multifaceted medicinal attributes [6]. Traditionally, it has been used by various tribes across the African continent, particularly by the Mpika tribe of Zimbabwe and Zulus of South Africa [6-8]. Unfortunately, high rates of deforestation and over-collection have severely depleted the natural populations of $A$. africana, making it rare, and the International Union for Conservation of Nature (IUCN) has declared it "vulnerable". It has been listed in the red list of rare, endangered and threatened (RET) plants [9]. To envisage and unlock the large medicinal uses of this unexplored orchid taxa, planned usage of plant tissue culture-based biotechnological approaches provides a sustainable alternative, sufficing the aspects of conservation as well as commercial exploitation [10,11].

Moreover, variation in the in vitro culture conditions, particularly plant growth regulators (PGRs), remarkably enhances metabolite synthesis. The biologically important compounds of pharmaceutical importance get deposited as a result of in vitro stress [12-14]. Traditionally, decoctions and infusions obtained from the roots and stem parts of A. africana are used to treat various chronic ailments and have been reported to possess strong antimicrobial activity against various bacterial and fungal pathogen strains $[4,15]$. Furthermore, A. africana extracts were shown to inhibit acetylcholinesterase activity, which may be a promising remedy to Alzheimer's disease [15]. Although there exists no baseline phytochemical data available on A. africana, terpenoids, flavonoids and alkaloidal compounds are responsible for these activities that might exist in the species through proper investigation. Nonetheless, very limited reports exist on pharmacological activities of the different parts of $A$. africana. Keeping in perspective the view about the immense potential of $A$. africana, the present research attempts to decipher the chemical composition and cytotoxic activity of essential oil and oleoresins obtained from micropropagated plants of A. africana. Extensive literature surveys revealed that the chemical composition along with cytotoxic activity of the essential oil and oleoresins from the micropropagated plants of A. africana have not been reported to date. This is the first approach of a phytochemical study on this orchid species.

\section{Results}

\subsection{Plant Tissue Culture of A. africana}

In the sustainable utilization of medicinal plant bio-resources (MAP), plant tissue culture plays a pivotal role. In the fast production of quality planting materials (QPM), plant growth regulators play a major role [16]. In the present research, we have utilized the plant material generated from the aromatic cytokinin-mediated regeneration pathway of $A$. africana as the source material for essential oil extraction [9] (Figure 1). The conducive role of aromatic cytokinin in producing higher secondary metabolites in medicinal plants has been well documented. Our previous research on A. africana PLB biomass has provided vital insights into the role of $m \mathrm{~T}$ and its derivatives in the upregulation of phenolic acid contents and subsequent antioxidant activity [12]. Furthermore, the protocol reported by Bhattacharyya et al. [9] ascertained a high degree of clonal fidelity, which is a prerequisite of any plant tissue culture-derived planting material [17]. Within a short time, genetically stable plant material was obtained for A. africana, which was further processed to extract essential oil. 

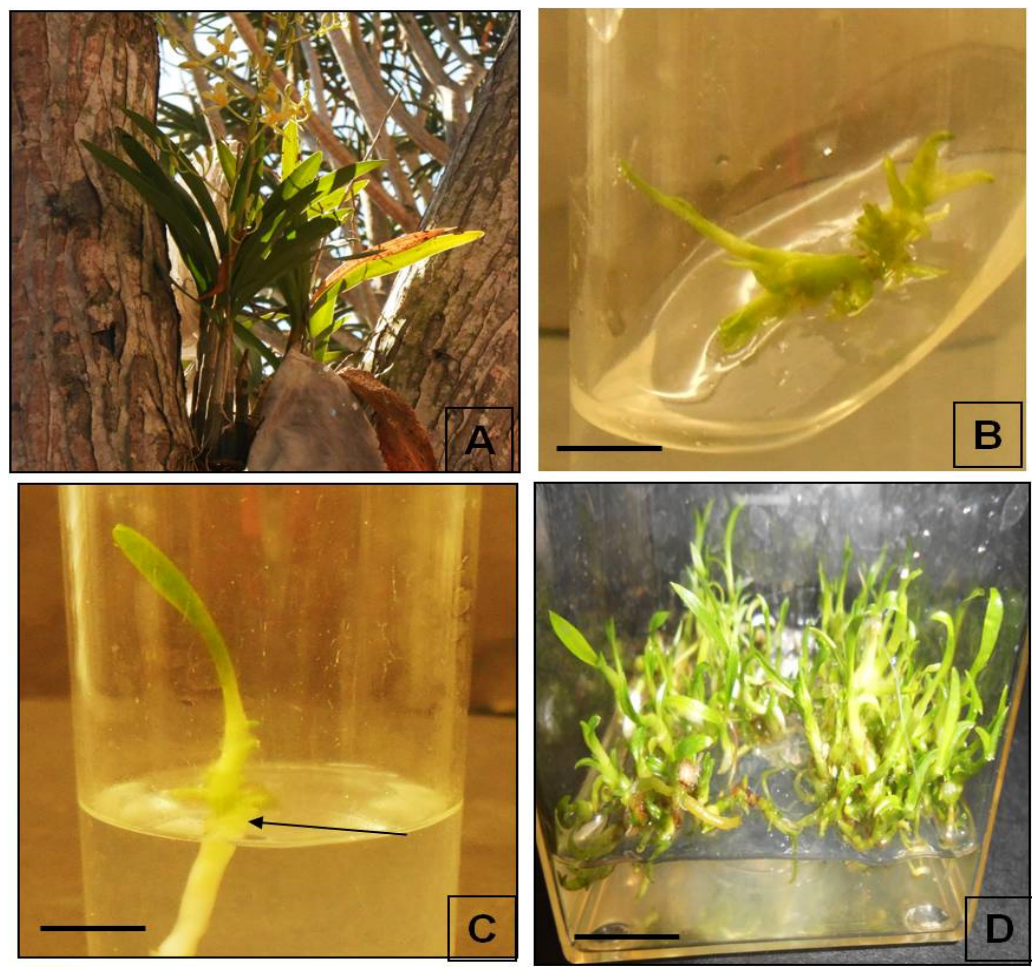

Figure 1. (A) Wild plants of A. africana in flowering condition, (B) culture initiation in MS medium $+10 \mu \mathrm{M} m \mathrm{~T}(\mathrm{bar}=2 \mathrm{~mm}),(\mathbf{C})$ induction of plantlets and growth in $+10 \mu \mathrm{M} \mathrm{mT}(\mathrm{bar}=2 \mathrm{~mm})$ after 15 days of culture initiation, and (D) proliferation of multiple shoots after 30 days when maintained in $10 \mu \mathrm{M} m \mathrm{~T}+5 \mu \mathrm{M}$ NAA (bar $=1 \mathrm{~cm}$ ).

\subsection{Chemical Composition of the Essential Oil and Oleoresins}

The highest yield of extract was obtained from acetone extract, with $3770 \mathrm{mg}$ (dry weight basis), followed by essential oil $(10 \mathrm{mg}$ ) and ethyl acetate extract $(5.3 \mathrm{mg})$ (fresh weight basis) in $100 \mathrm{~g}$ material. The colours of acetone, ethyl acetate and essential oil are brown gummy, transparent and slightly yellowish, respectively. The results of GC-MS analyses of essential oil, acetone and ethyl acetate extracts of $A$. africana are summarized in Table 1 and Figure 2.

Table 1. Chemical composition (\%) of the essential oil and oleoresins of A. africana.

\begin{tabular}{ccccc}
\hline & & & Composition (\%) \\
\hline Compounds & RI & Essential Oil & Acetone Ext. & EtOAc Ext. \\
\hline Aliphatic hydrocarbons & & & & \\
(1) 2,4,4-Trimethyl-1-hexene & 799 & 0.50 & & \\
(2) 2-Hexene, 2,5,5-trimethyl & 816 & 2.12 & & \\
(3) 2-Hexene, 3,4,4-trimethyl & 816 & 0.40 & & \\
(4) 2,3-Dimethyl-2-heptene & 878 & 0.46 & & \\
(5) Cyclopentane, 1,2,3,4,5-pentamethyl & 905 & 0.82 & & \\
(6) Nonane, 4,5-dimethyl- & 986 & 0.30 & & 0.70 \\
(7) Octane, 5-ethyl-2-methyl & 986 & 0.63 & & 0.60 \\
(8) n-Decane & 1015 & & & \\
(9) 1-Undecene, 4-methyl & 1140 & & & \\
(10) Dodecane & 1214 & & & \\
(11) Cycloxexane, (1,2,2-trimethylbutyl) & 1228 & 1.75 & & \\
(12) Dodecane, 2,6,11-trimethyl- & 1320 & 1.53 & & \\
(13) Tetradecane & 1413 & & & \\
(14) Pentadecane & 1512 & & 0.40 & \\
(15) Hexadecane, 4-methyl & 1647 & & 0.35 & \\
(16) Heptadecane & 1711 & 1.17 & 16.48 & 9.40 \\
\hline
\end{tabular}


Table 1. Cont.

\begin{tabular}{|c|c|c|c|c|}
\hline \multirow[b]{2}{*}{ Compounds } & \multirow[b]{2}{*}{ RI } & \multicolumn{3}{|c|}{ Composition (\%) } \\
\hline & & Essential Oil & Acetone Ext. & EtOAc Ext. \\
\hline (17) Heptadecane, 7-methyl & 1746 & & 0.21 & \\
\hline (18) Octadecane, 4-methyl & 1846 & & 0.40 & \\
\hline (19) Nonadecane, 2,3-dimethyl & 1980 & & 0.22 & \\
\hline (20) Eicosane & 2009 & 3.89 & 26.34 & 6.40 \\
\hline (21) Heneicosane & 2109 & & & 9.45 \\
\hline (22) 2-methyltetracosane & 2442 & 1.00 & & \\
\hline \multicolumn{5}{|l|}{ Aliphatic alcohols } \\
\hline (23) 2-Pentanone,4-hydroxy-4-methyl & 845 & & 11.13 & 4.79 \\
\hline (24) cis-4-Hexen-1-ol & 868 & 0.30 & & \\
\hline (25) 4,4,6-Trimethyl-cyclohex-2-en-1-ol & 1085 & 0.35 & & \\
\hline (26) Spiro[2.4] heptane-5-methanol, 5-hydroxy & 1208 & 0.49 & & \\
\hline (27) Pentadecanol & 1755 & & 1.12 & \\
\hline (28) 2-Pentadecyn-1-ol & 1772 & 3.77 & & \\
\hline (29) Nonadecanol & 2153 & & 1.57 & 0.82 \\
\hline (30) Lignoceric alcohol & 2650 & & 1.15 & \\
\hline \multicolumn{5}{|l|}{ Aliphatic aldehyde } \\
\hline (31) n-Hexanal & 806 & 0.88 & & \\
\hline (32) trans-2-Decenal & 1212 & 0.49 & & \\
\hline (33) Mesityl oxide & 739 & & 2.34 & \\
\hline \multicolumn{5}{|l|}{ Aliphatic acids and esters } \\
\hline (34) n-Butyl acetate & 785 & - & 21.13 & 14.34 \\
\hline (35) 4-Heptenoic acid, 3,3-dimethyl-6-oxo-methyl ester & 1242 & 0.49 & & \\
\hline (36) Myristic acid & 1769 & 0.46 & & \\
\hline (37) Pentadecanoic acid & 1869 & 1.31 & & \\
\hline (38) Palmitoleic acid & 1976 & 1.42 & & \\
\hline (39) Succinic acid, 3,7-dimethyloct-6-en-1-yl pentyl ester & 2165 & 0.68 & & \\
\hline (40) Linoleic acid & 2183 & 18.42 & 2.17 & \\
\hline (41) Linolenic acid & 2191 & 10.98 & & \\
\hline (42) l-Ascorbyl 2,6-Dipalmitate & 4765 & 11.50 & 0.46 & 1.28 \\
\hline \multicolumn{5}{|l|}{ Aromatic hydrocarbons } \\
\hline (43) Toluene & 794 & & & 2.54 \\
\hline (44) Ethylbenzene & 893 & 0.51 & 0.47 & 1.34 \\
\hline (45) $p$-Xylene & 907 & 1.53 & 2.28 & 5.24 \\
\hline (46) o-Xylene & 907 & & 0.70 & \\
\hline (47) 1-Triazene, 1-methyl-3-(4-methylphenyl) & 907 & & & 0.65 \\
\hline (48) Mesitylene & 1020 & 0.34 & 0.20 & 2.98 \\
\hline (49) o-Ethyltoluene & 1006 & & & 0.78 \\
\hline (50) m-Propyltoluene & 1106 & & & 0.62 \\
\hline (51) p-Diethylbenzene & 1106 & & & 1.07 \\
\hline (52) Benzene, 1-ethyl-2,4-dimethyl & 1119 & & & 0.93 \\
\hline (53) Benzene, 1-ethyl-3,5-dimethyl- & 1119 & & & 1.15 \\
\hline (54) Durene & 1133 & & & 1.84 \\
\hline \multicolumn{5}{|l|}{ Aromatic alcohols } \\
\hline (55) $p$-Cresol & 1014 & 9.99 & & \\
\hline (56) Erythro-1-Phenylpropane-1,2-diol & 1317 & & & 2.54 \\
\hline \multicolumn{5}{|l|}{ Aromatic aldehydes } \\
\hline (57) Styrene & 883 & 4.64 & & 22.20 \\
\hline (58) Benzaldehyde & 982 & 0.39 & & \\
\hline \multicolumn{5}{|l|}{ Aromatic ketones } \\
\hline (59) Hyacinthin & 1081 & 1.26 & & \\
\hline (60) Benzyl methyl ketone & 1128 & 1.64 & & \\
\hline \multicolumn{5}{|l|}{ Aromatic acids and esters } \\
\hline (61) 2-Ethylbutyric acid, 3-methylbenzyl ester & 1606 & 0.51 & & \\
\hline
\end{tabular}


Table 1. Cont.

\begin{tabular}{|c|c|c|c|c|}
\hline \multirow[b]{2}{*}{ Compounds } & \multirow[b]{2}{*}{ RI } & \multicolumn{3}{|c|}{ Composition (\%) } \\
\hline & & Essential Oil & Acetone Ext. & EtOAc Ext. \\
\hline \multicolumn{5}{|l|}{ Aromatic acids and esters } \\
\hline (62) Phthalic acid, diisobutyl ester & 1908 & & 1.03 & \\
\hline (63) Cyclohexanecarboxylic acid, 4-nitrophenyl ester & 2016 & 0.40 & & \\
\hline (64) Phthalic acid, dibutyl ester & 2037 & 0.79 & 0.44 & \\
\hline $\begin{array}{l}\text { (65) Cyclopropanecarboxylic acid, 1-(phenylmethyl)-, } \\
\text { 2,6-bis(1,1-dimethylethyl)-4-methylphenyl ester }\end{array}$ & 2775 & 0.37 & & \\
\hline \multicolumn{5}{|l|}{ Monoterpenoides } \\
\hline (66) Eucalyptol & 1059 & 1.38 & & \\
\hline (67) $\beta$-Linalool & 1082 & 2.26 & & \\
\hline (68) 1,7,7-Trimethyl-2-vinylbicyclo[2.2.1]hept-2-ene & 1111 & 0.68 & & \\
\hline (69) p-Menth-1-en-4-ol & 1137 & 0.31 & & \\
\hline (70) $\alpha$-Terpineol & 1143 & 1.11 & & \\
\hline (71) Dihydroedulan I & 1342 & 0.31 & & \\
\hline (72) Dihydroactinidiolide & 1426 & 0.72 & & \\
\hline (73) Trans-5-Isopropyl-6,7-epoxy-8-hydroxy-8-methyl & 1465 & 0.34 & & \\
\hline \multicolumn{5}{|l|}{ Oxygenated norisoprenoids } \\
\hline (74) Theaspirane & 1370 & 0.38 & & \\
\hline \multicolumn{5}{|l|}{ Sesquiterpenoides } \\
\hline (75) Cadalene & 1706 & 0.66 & & \\
\hline $\begin{array}{c}\text { (76) 3-Isopropyl-6,7-dimethyltricyclo }[4.4 .0 .0(2,8)] \\
\text { decane-9,10-diol }\end{array}$ & 1710 & 0.52 & & \\
\hline (77) Hexahydrofarnesyl acetone & 1754 & 0.30 & 0.30 & \\
\hline \multicolumn{5}{|l|}{ Azulene molecules } \\
\hline $\begin{array}{l}\text { (78) Ethanone, } \\
\text { 1-(1,3a,4,5,6,7-hexahydro-4-hydroxy-3,8-dimethyl-5-azulenyl) }\end{array}$ & 1758 & 0.36 & & \\
\hline \multicolumn{5}{|l|}{ Diterpenoids } \\
\hline (79) Phytol & 2045 & & 0.78 & \\
\hline (80) Phytol, acetate & 2168 & & 1.16 & \\
\hline (81) Cyclotetrasiloxane, octamethyl & 827 & 0.35 & & 0.91 \\
\hline (82) Cyclopentasiloxane, decamethyl & 1034 & 0.94 & & 2.97 \\
\hline (83) 2,5-Pyrrolidinedione, 3-ethyl-1,3-dimethyl & 1326 & 0.44 & & \\
\hline (84) 1,8 (2H,5H)-Naphthalenedione, hexahydro-8a-methyl-, cis & 1517 & 0.46 & & \\
\hline Total (\%) & & 100 & 100 & 100 \\
\hline Total (number of compounds) & & 55 & 26 & 26 \\
\hline
\end{tabular}

Note: The retention indices (RI) of compounds determined on Zebron ZB5MS-plus column using GC-FID.

The presence of aliphatic hydrocarbons, acids and esters are the characteristic feature of the samples under investigation. The highest amounts of aliphatic acids and esters were found in the essential oil ( $45.26 \%)$, followed by acetone (23.76\%) and ethyl acetate extracts $(15.62 \%)$. On the other hand, acetone extract contained the highest portion of aliphatic hydrocarbons (51.57\%) compared to the other two samples-ethyl acetate $(31.01 \%)$ and essential oil (14.57\%). In addition, aromatic aldehydes (22.2\%) and hydrocarbons (19.14\%) were predominantly found in ethyl acetate extract. Furthermore, aromatic alcohols were present in essential oil $(9.99 \%)$ and ethyl acetate extracts $(2.54 \%)$, while monoterpenoides $(7.11 \%)$ are present in essential oil. Sesquiterpenoides were recorded in minute quantities $(1.48 \%)$ in essential oil. 


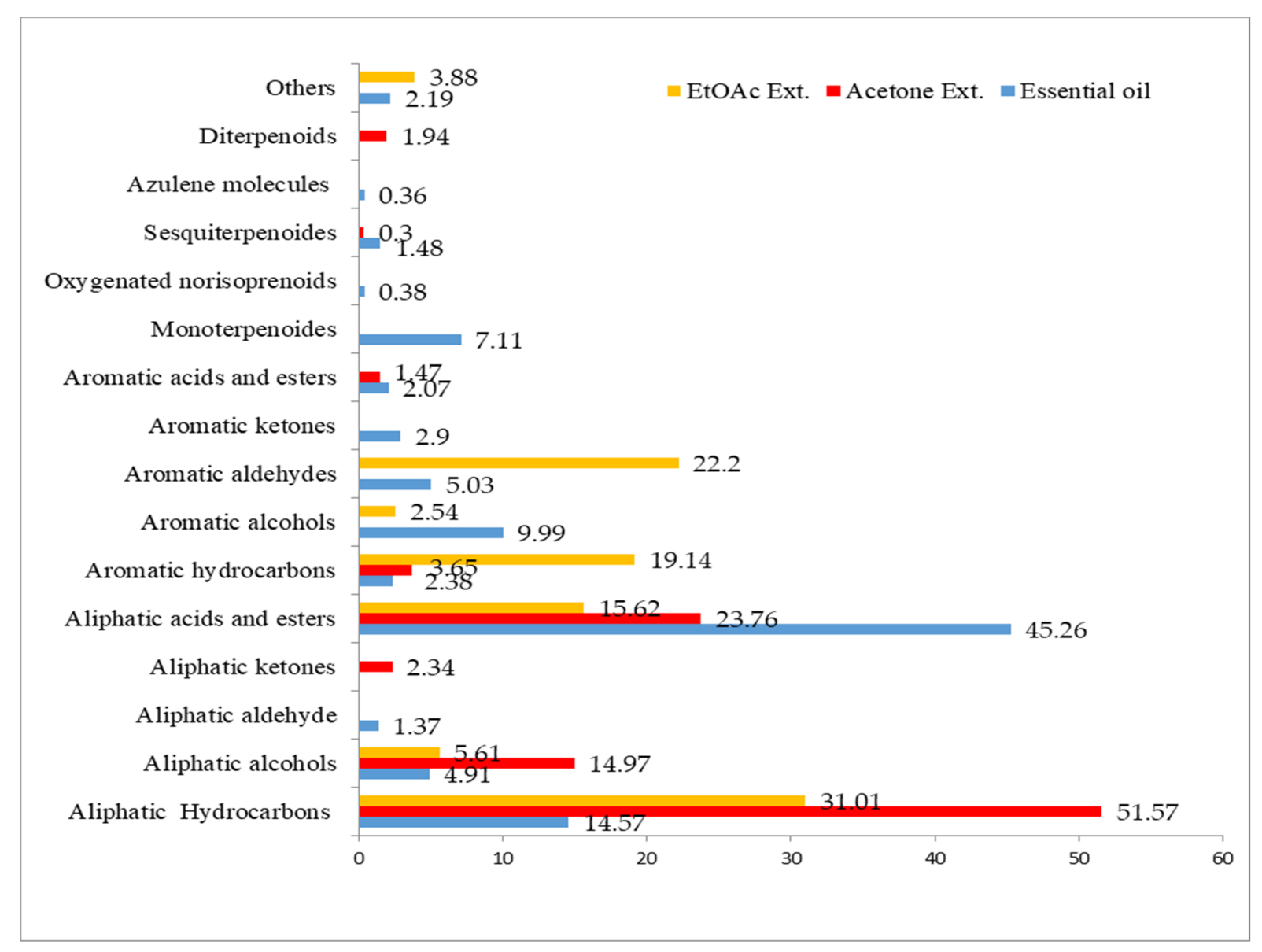

Figure 2. Major identified compounds (in \%) of micropropagated plants of A. africana.

GC-MS analysis showed 55 compounds in the essential oil that constituted $100 \%$ of the total oil. Linoleic acid $(18.42 \%)$ was the major constituent in the oil, followed by $l$-ascorbyl 2,6-dipalmitate (11.50\%), linolenic acid (10.98\%), erythro-1-phenylpropane-1,2-diol (9.99\%), styrene $(4.64 \%)$, eicosane $(3.89 \%)$ and 2-pentadecyn-1-ol (3.77\%). In the acetone extract, 26 compounds were identified and accounted for $100 \%$ of the total extract. It was found to be rich in eicosane $(26.34 \%)$. The other major components were-n-butyl acetate $(21.13 \%)$, heptadecane $(16.48 \%)$ and tetradecane $(6.60 \%)$. In this study, 26 compounds were also successfully identified from the ethyl acetate extract, which made up $100 \%$ of the total amount. The predominant constituents of ethyl acetate extract were styrene $(22.20 \%)$, n-butyl acetate $(14.34 \%)$, heneicosane $(9.45 \%)$, heptadecane $(9.40 \%)$, eicosane $(6.40 \%)$, $p$-xylene $(5.24 \%)$, 2-pentanone, 4-hydroxy-4-methyl $(4.79 \%)$ and tetradecane $(3.83 \%)$. Overall, this is the first result on the chemical composition of essential oil and oleoresins from the micropropagated plants of $A$. africana. The GC-MS chromatogram of the predominant components are shown in the plants in Figure 3 (details are presented in the Supplementary Figure S1). The structures of a few major compounds are shown in Figure 4. 

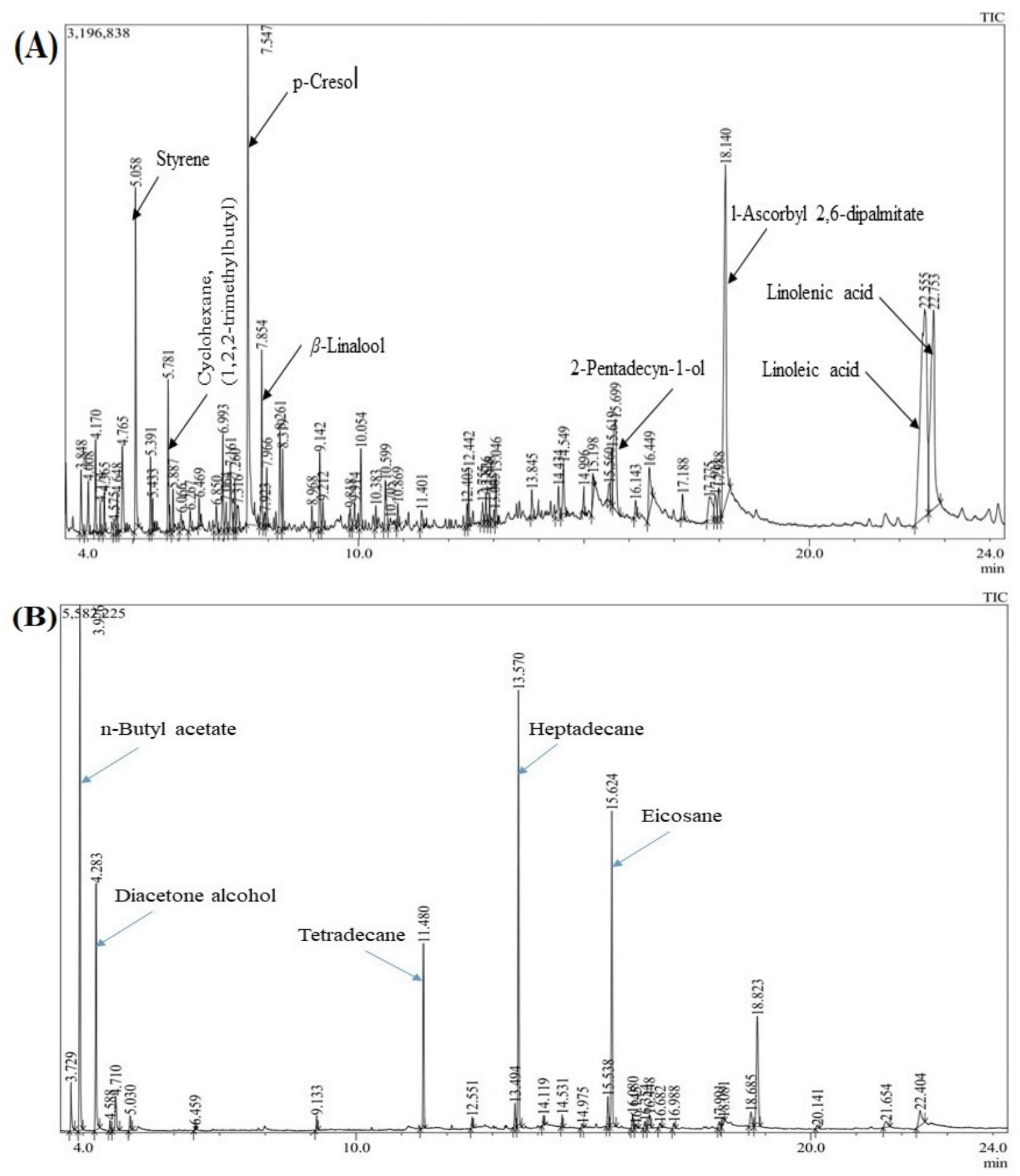

Figure 3. Cont. 
(C)

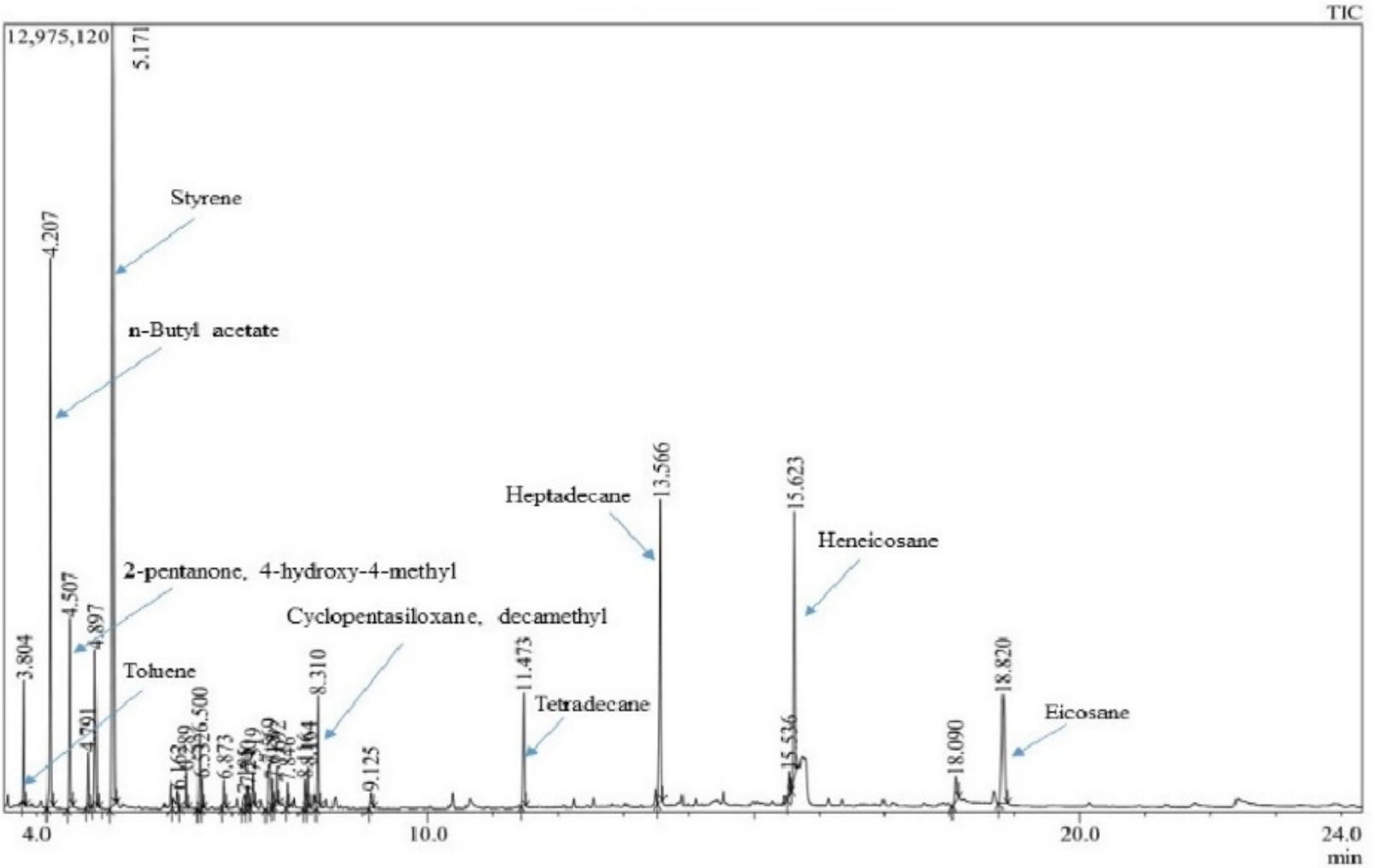

Figure 3. Chromatographic profile of (A) essential oil and oleoresins (B) acetone and (C) ethyl acetate from $A$ africana micropropagated plants (details are presented in the Supplementary Figure S1).

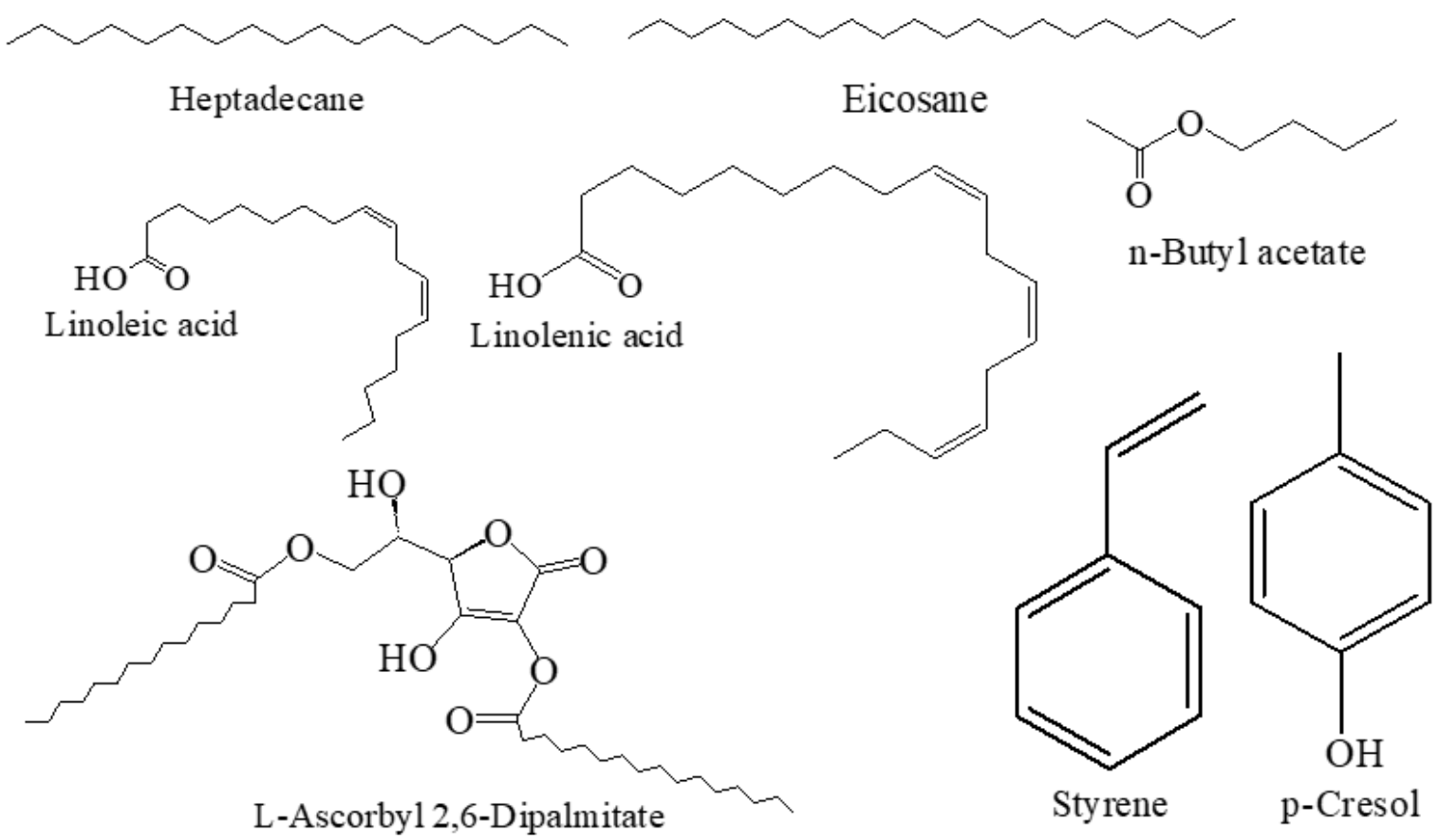

Figure 4. Major identified compounds of micropropagated plants of A. africana.

\subsection{PCA Analysis of the Essential Oil and Oleoresins}

The score plot (Figure 5) shows the relationship between different extracts (the observations) and the loading plot shows how strongly each characteristic influences a PC (other variables). The first principal component (PC), PC1, explained nearly $51 \%$ of the data 
variability and the second PC (PC2) explained roughly 32.93\%, retaining roughly $83.93 \%$ of all variability in the experimental data. Materially, three principal components would explain $100 \%$ of the total variation.

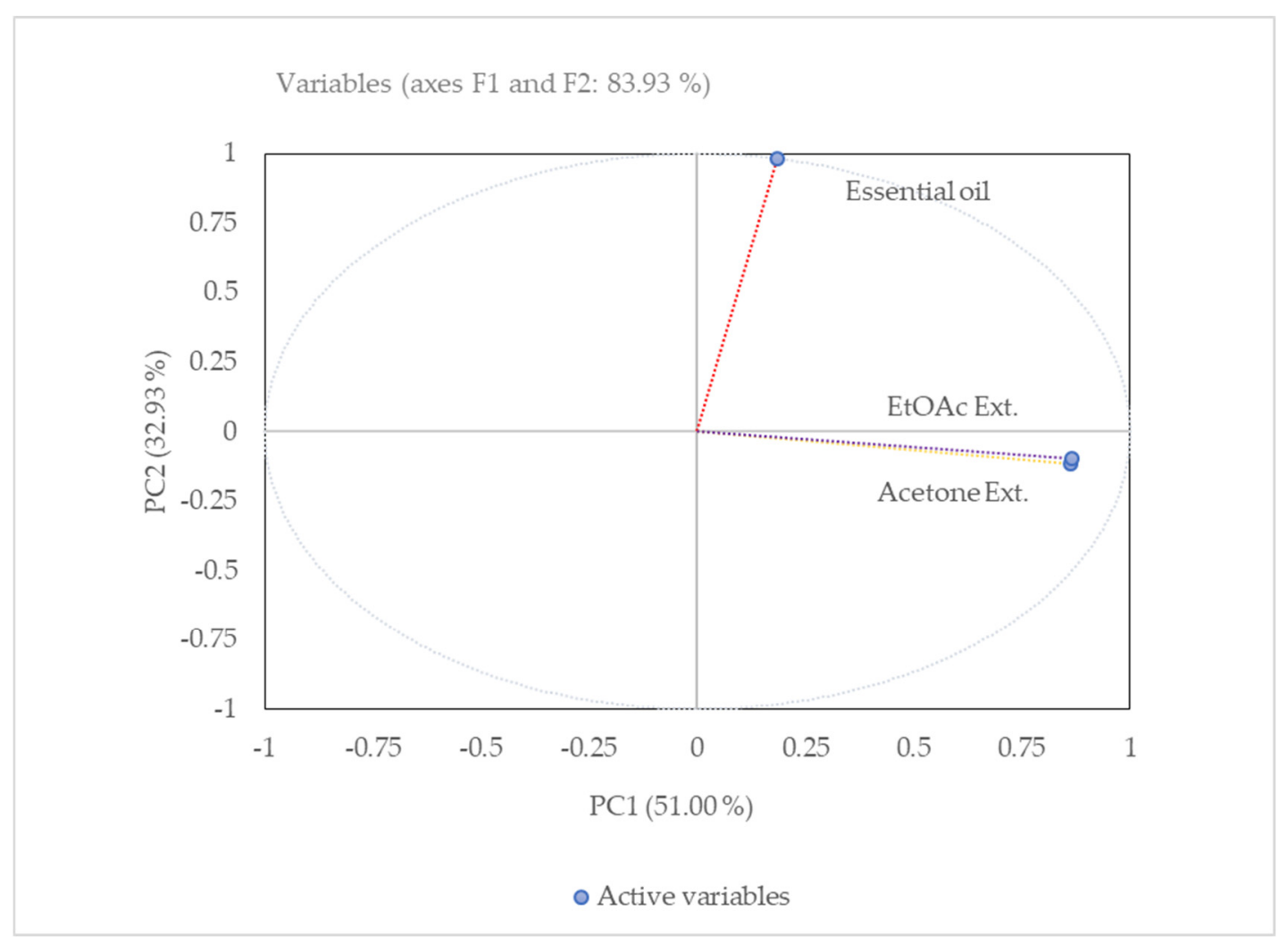

Figure 5. Principal component analysis (PCA) of the correlation between the essential oil and oleoresins composition based on GC-MS results.

\subsection{The Cytotoxicity of the Essential Oil and Oleoresins}

The cytotoxic activity of the essential oils and oleoresins from the micropropagated $A$. africana on Vero cells is depicted in Table 2. The present investigation is the first report on the cytotoxic effects of essential oil and oleoresins. The essential oil showed cytotoxic activity with an $\mathrm{LC}_{50}$ value of $52.53 \mu \mathrm{g} / \mathrm{mL}$ followed by the acetone extract $(25.64 \mu \mathrm{g} / \mathrm{mL})$ and ethyl acetate extract $(60.05 \mu \mathrm{g} / \mathrm{mL})$. However, they were not comparatively as cytotoxic as the anticancer drug doxorubicin hydrochloride $(3.46 \mu \mathrm{g} / \mathrm{mL})$. The essential oil and acetone extract showed the highest cell morality at the dose of $1000 \mu \mathrm{g} / \mathrm{mL}$ (Figure 6). The table shows that the cytotoxic activity of the essential oil differed fractionally with respect to the ethyl acetate extract, however, the acetone extract showed a significant difference in activity with respect to the essential oil and ethyl acetate extract.

Table 2. Extraction yields and cytotoxic activity of essential oil and oleoresins of A. africana.

\begin{tabular}{ccc}
\hline Extract & Extraction Yield (mg/100g) & Cytotoxicity Using Vero Cell Line ${ }^{\text {a }}\left(\mathbf{L C} \mathbf{5 0}_{\mathbf{5 0}} / \mathbf{m L}\right)$ \\
\hline Essential oil & 10 & $52.53 \pm 0.69$ \\
Ethyl acetate extract & 5.3 & $60.05 \pm 1.46$ \\
Acetone extract & 3770 & $25.64 \pm 0.78$ \\
Doxorubicin hydrochloride & & $3.46 \pm 0.18$ or $(5.97 \mu \mathrm{M} / \mathrm{mL})$ \\
\hline
\end{tabular}

${ }^{a}$ Normal adult African green monkey kidney cells. All data represent the mean \pm standard deviation. Number of samples: three $(n=3)$ with eight replicates, the significant difference was calculated at $p \leq 0.05$. 


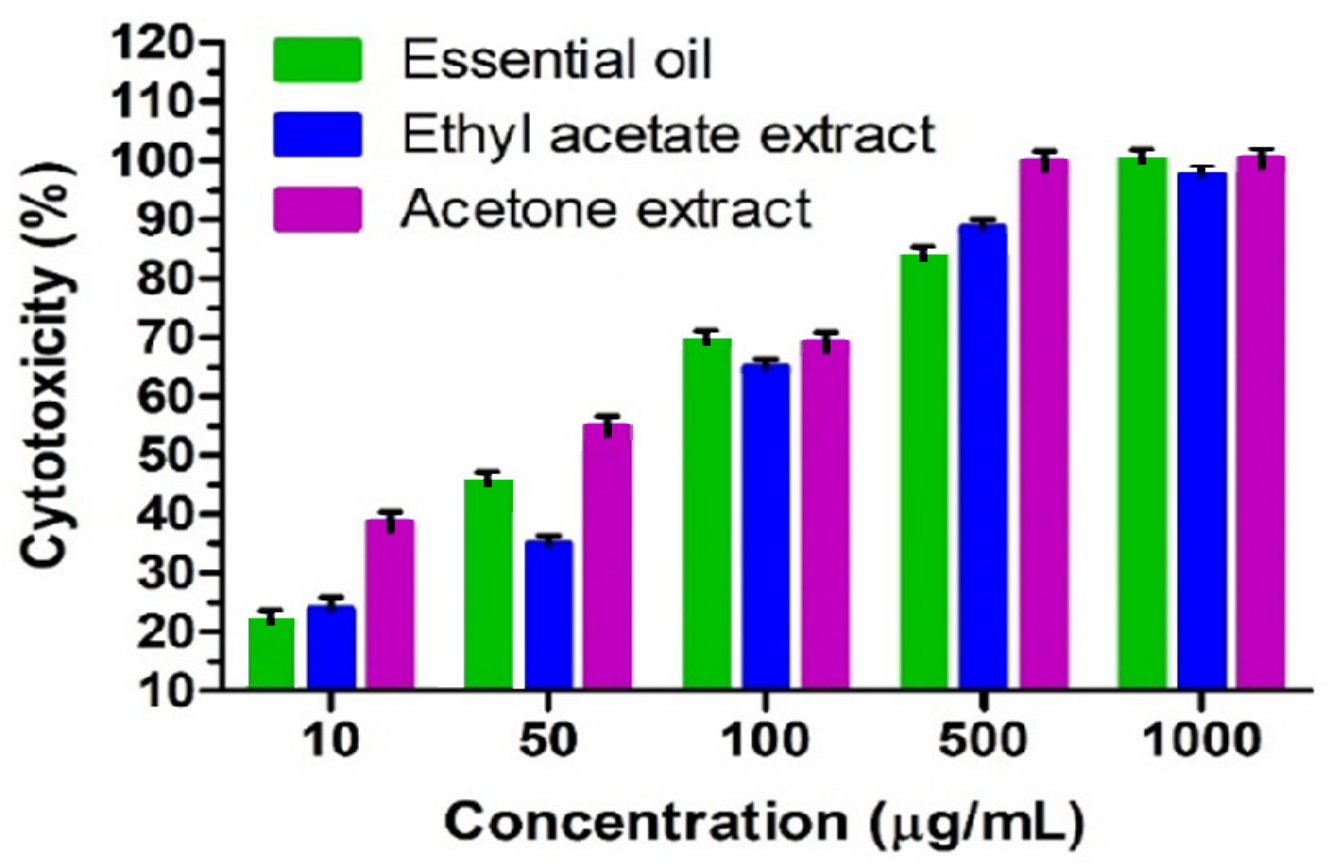

Figure 6. In vitro cytotoxicity percent (\%) of A. africana essential oil and oleoresins with different concentrations on the Vero cell line by MTT assay. The data represent mean \pm standard error of the mean of three independent samples with eight replicates $(\mathrm{n}=8), p \leq 0.05$.

\section{Discussion}

Plant tissue culture techniques offer an effective alternative for the regulated production of pharmaceutically important secondary metabolites under a controlled laboratory atmosphere with special reference to the essential oil production [18,19]. Furthermore, in vitro propagation-based approaches are also used to produce mass production of chemically stable, metabolically rich and economically profitable plants [20]. The present research further validates the conducive role of an in vitro propagation module in the quantitative production of the twelve major entities (namely $p$-cresol, styrene, linoleic acid, heptadecane, tetradecane, eicosane, heneicosane, 2-pentanone, 4-hydroxy-4-methyl, l-ascorbyl 2,6-dipalmitate and n-butyl acetate) along with other non-major components, which are in close synergy with micropropagated Lavandula dentate essential oil. The report showed that IBA could be able to increase the essential oil composition in micropropagated $L$. dentate [21]. Similarly, in in vitro propagated Ajuga bracteosa shoots, remarkable changes in the essential oil yield were reported mainly in the levels of $\alpha$-terpinene, $\gamma$-terpinene and terpinolene when treated with varying concentrations of IBA [22] Like-wise, $m$ T treatment has also been reported to influence the chemical composition of important MAPs like phytol [23]. In addition, Ali et al. [22] reported the positive correlation between the biosynthesis of volatile organic compounds and in vitro shoot regeneration in the different developmental stages of $A$. bracteosa. Nonetheless, to date, the exact mechanism is not fully understood with respect to the biosynthesis of volatile compounds that are enhanced under PGR treatments. Hence, further investigations are needed to understand the biosynthesis mechanism of the essential oil compounds under PGR treatment.

The GC-MS results revealed that the essential oil and oleoresins constituted a complex mixture of aliphatic and aromatic hydrocarbons, alcohols, aldehydes, ketones, azulenes, acids and esters, terpenoids such as monoterpenoides, oxygenated norisoprenoids, sesquiterpenoides, diterpenoids along with other miscellaneous constituents. The identified major constituents were also found in other plant species that exhibited close synergy with present research findings. In this context, 2-pentanone, 4-hydroxy-4-methyl (diacetone alcohol) has been identified in Stachys laxa (12.3\%) essential oil [24] which was found to be similar (11.13\%) in acetone extracts. In addition, eicosane and heneicosane were 
identified as high amounts (24.0 and 10.9\%) in the aerial parts of Micromeri ajuliana [25], and eicosane was a major constituent in the essential oil of the leaves of Barringtonia asiatica (27.4\%) [26] which was found to be as high at $26.34 \%$ and $9.45 \%$ in the current study, respectively. Besides, heneicosane was also identified at $8.4-14.1 \%$ in in vivo and in vitro cultures of Caryopteris species [27] On the other hand, the GC-MS analysis of the leaf oils of Elephantopus scaber L. (from 12 locations in southern China) led to the identification of $n$-tetradecane (1.19-5.26\%) and $n$-heptadecane (2.48-15.32\%) as the major compounds with other constituents [28] which can be compared to our present study.

In such an investigation, styrene has been identified in many foodstuffs such as cereals, fruits, coffee beans, olive oil, beer, beef meat and cinnamon. Styrene can be produced from cinnamaldehyde in cinnamon by an oxidative degradation followed by an intermediate stage of cinnamic acid via decarboxylation. The WHO-recommended level of styrene is $7.7 \mu \mathrm{g} / \mathrm{kg}$ body weight per day for an adult as a tolerable daily intake [29] The amount of styrene in cinnamon is high-levels of $40 \mathrm{mg} / \mathrm{kg}$ have been reported [30] Furthermore, styrene was also identified in the essential oil of Herba taxilli $(11.42 \%)$ and styrax gums $(70.4 \%$ and $30.9 \%)$ of two different varieties [31,32] and also in Peganum harmala smoke and volatile oil (4.2\%) [33] which were detected in a significant amount $(4.64 \%$ and $22.20 \%)$ in the current study. In the case of $p$-cresol, it was detected in Mutellina purpurea flower essential oil (17.4\%) [34] and the volatile extract from rhizomes of Cnidium officinale $(10.17 \%)$ [35] In that case, $p$-cresol is a compound of $A$. africana, which was detected at $9.99 \%$ like other volatile constituents. Nonetheless, all the compounds were identified from the different extracts of $A$. africana for the first time by the micropropagation method.

In the context of solvent extraction, the impact of selected aqueous and organic solvents played an important role in the extraction of constituents and their subsequent cytotoxic effect. The extraction efficiency of the phytochemicals highly depends on the polarity index, extraction technique, extraction time and applied temperature. In the current study, we chose three types of solvent and temperature frames to extract the compounds that produced various compositions in the different extracts. The results showed that the aqueous extract had high levels of certain specific compounds which are not found in the acetone or ethyl acetate extract or found in low amounts, and vice-versa. Therefore, the variation of cytotoxic effect was observed in the different extracts. From the GC analysis (Figure 3), some high amount peaks in the extracts can be further isolated for various biological properties such as anticancer properties.

The principal component analysis (PCA) has been performed to reduce the dimensions of the data set, for co-relation, and to discriminate the essential oil and oleoreisns' chemical compositions. Based on the PCA analysis, the three samples were grouped into two different clusters. Ethyl acetate and acetone extracts were positively co-related in the first principal component PC1, whereas essential oil was negatively correlated in the second cluster of PC2. Graphically, ethyl acetate and acetone extracts that are close to each other in the score plots have similar chemotypes. It was observed that the number of principal components depends on the number of variables, as the percent of total variance increases with a lower number of variables. Usually, the proportion of total variance decreases by increasing the number of variables. Furthermore, ethyl acetate and acetone extracts were clustered together because of the presence of dodecane, tetradecane, heptadecane, eicosane, 2-pentanone, 4-hydroxy-4-methyl, nonadecanol and n-butyl acetate compounds.

According to the plant screening program (in vitro cytotoxic activity) of the American National Cancer Institute (NCI), the limit of toxicity of plant crude extracts at $50 \%$ inhibition $\left(\mathrm{IC}_{50}\right)$ of proliferation is less than $20 \mu \mathrm{g} / \mathrm{mL}$ (incubation between 48 and $72 \mathrm{~h}$ ), while it is set at less than $4 \mu \mathrm{g} / \mathrm{mL}$ for pure compounds [36] Based on NCI, essential oil and oleoresins showed a non-toxic effect in the present investigation, where the percent of cytotoxicity has shown a dose-dependent graph (Figure 6) of the studied samples according to the concentrations. On the other hand, the bioactivity of the essential oil and oleoresins may be responsible for their predominant compounds (Figure 3) or synergistic effect of major and minor compounds due to their reported broad pharmacological activities. Micropropagated 
plants of $A$. africana contained a higher percentage of heptadecane, eicosane, n-butyl acetate, styrene, $p$-cresol and fatty acid constituents such as linoleic, linolenic acids and $l$-ascorbyl 2,6-dipalmitate. Although these compounds are the major volatiles in A. africana, they were also isolated in pure form in other plant species. These predominant components are reported to have numerous pharmacological uses, especially with cytotoxic and anticancer effects. Heptadecane, eicosane and n-butyl acetate were present as the most predominant component in the oleoresins (acetone and ethyl acetate extracts), and have been reported to have anti-inflammatory and antimicrobial effects [37] cytotoxic effects on HeLa and MCF7 cell lines, and antimicrobial, larvicidal [38] and cytotoxic [39] properties, respectively. Styrene was also reported as genotoxic, cytotoxic and mutagenic [40-43], and has been detected in high amounts in ethyl acetate extract in the current investigation. $p$-Cresol and fatty acid constituents of linoleic, linolenic acid and $l$-ascorbyl 2,6-dipalmitate were present in a relatively significant amount in essential oil. $p$-Cresol was widely reported as a cytotoxic compound against different cell lines such as EA.hy926 (EAHY) endothelial and U937 cells, renal epithelial tubular cells, RAW264.7 cells and Bluegill Sunfish BF-2 cells [44-47].These fatty acids are well-reported for their anticancer and cytotoxic activities, and for their diverse pharmacological actions. Linoleic acid suppressed colorectal cancer cell growth [48] and inhibited the growth of human ovarian carcinoma cells (A2780) and induced mitochondrial-related apoptosis [49] and showed cytotoxicity to Bovine Lens Epithelial Cells [50]. Linolenic acid was reported to have activity against breast cancer [50] and promoted mitochondrial apoptosis for mammary gland chemoprevention [51,52], and was cytotoxic to fresh human tumour cells [53]. Recently, l-ascorbyl 2,6-dipalmitate was reported for its antitumour, antibacterial [54] anticarcinogen [55] cytotoxicity [56] and antiproliferative [57] activities. The rich content of linoleic acid, $l$-ascorbyl 2,6-dipalmitate, linolenic acid and erythro-1-phenylpropane-1,2-diol in the essential oil could suggest its potential medicinal value due to their cytotoxic and anticancer properties. The cytotoxic effect of the current study may be due to the major compounds of the essential oil and oleoresins or may be due to synergistic effects of the various compounds in the studied samples at different ratios. The possible mechanism of the cytotoxic activity depends on chemical constituents and experimental cells that are not known at this stage. The mechanisms of the cytotoxic activity can be described in many ways, which depend on the nature of compounds and experimental cells. The essential oils are responsible for some lipophilic compounds that can pass through the cytoplasmic membrane of the cells and degrade its lipoprotein structure [58] Another reason may be cellular toxicity mediated by disturbances in cellular homeostasis of calcium ions, increasing ROS production or unspecific disturbances in the inner mitochondrial membrane of the cells [59]. Further studies are required to unravel the mechanism of action by first isolating and characterizing the bioactive constituents from A. africana. This investigation provides useful information for pharmaceutical industries for the formulation of new medicinal or herbal products.

\section{Material and Methods}

\subsection{Chemicals}

Bacteriological Agar powder was purchased from Du Pont de Nemours Int., South Africa and Oxoid Ltd., Basingstoke, Hampshire and England. Naphthalene acetic acid (NAA), Indole-3-butyric acid (IBA), Phloroglucinol (PG), myo-inositol, vitamins (thiamine $\mathrm{HCl}$, nicotinic acid, pyridoxine $\mathrm{HCl}$ ) and glycine, were obtained from Sigma Aldrich, Germany. meta-Topolin $(m \mathrm{~T})$ was prepared as described previously $[60,61]$. The compounds 3-(4, 5-Dimethylthiazol-2-yl)-2, 5-diphenyltetrazolium Bromide (Sigma Aldrich, Darmstadt, Germany) Minimal Essential Medium (MEM) (Whitehead Scientific, Winelands Close, Stikland, 7530, South Africa), Gentamicin (Virbac, Carros, France), Foetal Calf Serum (Highveld Biological, Johannesburg, South Africa) and Doxorubicin chloride (Pfizer Laboratories, 85 Bute Lane, Sandton, 2146, South Africa) and Phosphate Buffered Saline (PBS) (Whitehead Scientific, Winelands Close, Stikland, 7530, South Africa) were used. All chemicals used in the assays were of analytical grade. 


\subsection{Micropropagation and Material Generation from A. africana}

Mature plants of $A$. africana were sampled from wild habitats and were maintained in the greenhouse of the University of KwaZulu-Natal (UKZN), Pietermaritzburg, South Africa (Figure 1A). Capsules were sampled from these maintained plant germplasms and were germinated asymbiotically on Murshige and Skoog (MS) medium [62] following the protocol described by Vasudevan and Van Staden [63]. From the germinated seedlings of A. africana, nodal explants (Figure 1B) were excised and were cultured in MS medium augmented with 3\% sucrose (Merck, KGaA, Darmstadt, Germany), 0.8\% agar (Oxoid, Hampshire, United Kingdom) and were micropropagated using $10 \mu \mathrm{M} m \mathrm{~T}+5 \mu \mathrm{M}$ NAA $+15 \mu \mathrm{M}$ IBA $+30 \mu \mathrm{M}$ PG in accordance with the protocol described by Bhattacharyya et al. [9]. The $\mathrm{pH}$ of the medium was adjusted to 5.8 before autoclaving at $121{ }^{\circ} \mathrm{C}$ for $15 \mathrm{~min}$. For each treatment, 5 replicates were taken, and the experiments were repeated in triplicate. All cultures were maintained at $25 \pm 2{ }^{\circ} \mathrm{C}, 80 \% \mathrm{RH}$ (Relative Humidity), and $12 \mathrm{~h}$ photoperiod at $50 \mu \mathrm{mol} / \mathrm{m}^{-2} / \mathrm{s}^{-1}$ irradiances provided by cool-white fluorescent tubes (OSRAM, Munich, Germany). Proliferated multiple shoots with roots (Figure 1C,D) were harvested after 10 weeks from the cultures and were used as sample material [9] for subsequent essential oil and oleoresin extraction and chemical profiling.

\subsection{Extraction}

Fresh propagated plant material of $A$. africana was subjected to hydro distillation using a Clevenger-type apparatus for $4 \mathrm{~h}$ to obtain the essential oil. Oleoresins (ethyl acetate and acetone extract) were prepared by the solvent extraction method. First, oleoresin was prepared from the emulsified water (residual water part after extraction of the essential oil) by extracting with ethyl acetate solution and dried by vacuum rotary evaporator under high pressure at $35-37^{\circ} \mathrm{C}$. The oil and extracted portion were dried through sodium sulphate. Secondly, another portion of orchid materials was air-dried at room temperature in the shade and subsequently pulverized. The powder material $(9.63 \mathrm{~g})$ was then extracted with acetone by Soxhlet apparatus in a temperature controlled $\left(60\right.$ to $\left.80^{\circ} \mathrm{C}\right)$ heating mantle for $72 \mathrm{~h}$. The extracted samples were stored at $4{ }^{\circ} \mathrm{C}$ until further analyses.

\subsection{Analysis of the Essential Oils}

The essential oils and oleoresins were analysed using GC-2010 and GC-MS QP 2010 SE (Shimadzu Corporation Japan) via Electron Impact Ionization (EI) method, which was fitted with a Zebron ZB5MS-plus (Phenomenex, Inc., Torrance, CA, USA) capillary column. The initial column $\left(30 \mathrm{~m} \times 0.25 \mathrm{~mm}, 0.25 \mu \mathrm{m}\right.$ film thickness) oven temperature was $40{ }^{\circ} \mathrm{C}$ (hold for $1 \mathrm{~min}$ ). The injection temperature was $200{ }^{\circ} \mathrm{C}$ (hold for $10 \mathrm{~min}$, at the rate of $12{ }^{\circ} \mathrm{C} / \mathrm{min}$ ). The carrier gas was helium at a constant pressure of $72.3 \mathrm{kPa}$ (acquisition parameters set to full scan and start at $50 \mathrm{~m} / z$ and end at $700 \mathrm{~m} / z$ ). The split ratio was 5.0 , and the ionization energy was $70 \mathrm{eV}$. The compounds were identified (FID detector) by comparing retention indices with the internal reference mass spectral NIST (National Institute of Standards and Technology) 11 library.

\subsection{Cytotoxicity Assay}

The colorimetric assay of MTT (3-(4,5-dimethylthiazol-2-yl)-2,5-diphenyltetra-zolium Bromide) was used to determine the viable cell growth after incubation of Vero cells with the extracts, according to the method [64-66] with slight modification. Minimal Essential Medium (MEM) was used to grow Vero cells supplemented with $0.1 \%$ gentamicin and $5 \%$ fontal calf serum. Cells of a sub-confluent culture were harvested, centrifuged (at $200 \times \mathrm{g}$ ) for $5 \mathrm{~min}$ and re-suspended in MEM to $5 \times 10^{4}$ cells $/ \mathrm{mL}$. The concentration of the extract was $10 \mathrm{mg} / \mathrm{mL}$. From the mother solution, five concentrations $(1,0.5,0.1,0.05$ and $0.01 \mathrm{mg} / \mathrm{mL}$ ) were applied with eight replicates (sample number $=3$ ) to the 96-well plate. The reference drug was used as doxorubicin chloride. The absorbance was measured in a microplate reader (Chromate 4300, Awareness Technology, Palm City, FL 34990, USA) 
according to the methods. The $\mathrm{LC}_{50}$ values were calculated from the linear regression Graph by Microsoft Excel10 version software.

\subsection{Statistical Analysis}

Means, SD, SEM calibration curves (with $95 \%$ confidence interval, $p \leq 0.5$ ) and linear regression analyses (R2) were determined using Microsoft Excel 2016 (Microsoft Corporation, Redmond, WA, USA). Cytotoxicity analysis was carried out by eight replicates for each plate and three independent experiments. The cell cytotoxicity (\%) was calculated by using GraphPad Software 5.0 for Windows (San Diego, CA, USA). In order to check corelation quantitative chemical composition among the different extracts, Pearson's correlation coefficients were calculated. The probability values below $5 \%$ were regarded as significant. For the multivariate projection of samples on the two-dimensional plane, principal component analysis (PCA) was carried out through XLSTAT Statistical Software using Microsoft Excel 2016.

\section{Conclusions}

Identification and quantification of the chemical composition in the essential oils and oleoresins or extracts are important to ensure the quality and safety of raw ingredients for herbal preparation. The documented results imply that acetone extract had the highest extractable solids, followed by ethyl acetate and water, indicating that the yield of extracts could be significantly affected by the solvents. It also indicates that maceration with acetone, ethyl acetate and water were successful techniques for extracting various types of compounds from A. africana. Therefore, the chemical compositions and cytotoxic activity are worthwhile to evaluate the toxicity and potential new source of antitumour compounds from the micropropagated A. africana. The current cytotoxic action of $A$. africana was much less than the standard drug. The studied cytotoxic effect might be responsible for the predominant components as well as synergistic action of minor components of essential oil and oleoresins. Further studies are required to isolate the dominant components from the micropropagated plants of $A$. africana to determine the exact reason for the cytotoxic activity. Overall, the present investigation would promise future application to the food and herbal industries due to the low toxic effect of the essential oils and oleoresins.

Supplementary Materials: The following are available online, Figure S1: GC-MS Chromatogram of essential oil (A), acetone extract (B) and ethyl acetate extract (C).

Author Contributions: Conceptualization, M.M.S.-E.-I. and P.B.; methodology, M.M.S.-E.-I. and P.B.; software, M.M.S.-E.-I. and P.B.; formal analysis, M.M.S.-E.-I. and P.B.; investigation, M.M.S.-E.-I. and P.B.; resources, M.M.S.-E.-I. and P.B.; data curation, M.M.S.-E.-I. and P.B.; writing-review and editing, M.M.S., P.B. and J.V.S.; visualization, M.M.S.-E.-I., P.B. and J.V.S.; supervision, J.V.S. All authors have read and agreed to the published version of the manuscript.

Funding: University of KwaZulu-Natal, South Africa for postdoctoral fellowships.

Institutional Review Board Statement: Not applicable.

Informed Consent Statement: Not applicable.

Data Availability Statement: The data presented in this study are available on request from the corresponding author.

Acknowledgments: M.M.S.-E.-I. and P.B. are thankful to the University of KwaZulu-Natal, South Africa for financial support in the form of postdoctoral fellowships.

Conflicts of Interest: The authors declare no conflict of interest.

Sample Availability: Samples of the compounds are available from the authors. 


\section{References}

1. Dias, M.I.; Sousa, M.J.; Alves, R.C.; Ferreira, I.C.F.R. Exploring plant tissue culture to improve the production of phenolic compounds: A review. Ind. Crops Prod. 2016, 82, 9-22. [CrossRef]

2. Saleh-E-In, M.M.; Van Staden, J. Ethnobotany, phytochemistry and pharmacology of Arctotis arctotoides (L.f.) O. Hoffm.: A review. J. Ethnopharmacol. 2018, 220, 294-320. [CrossRef] [PubMed]

3. Gurib-Fakim, A. Medicinal plants: Traditions of yesterday and drugs of tomorrow. Mol. Asp. Med. 2006, 27, 1-93. [CrossRef] [PubMed]

4. Penduka, D.; Mthembu, W.; Cele, K.H.; Mosa, R.A.; Zobolo, A.M.; Opoku, A.R. Extracts of Ansellia africana and Platycarpha glomerata exhibit antibacterial activities against some respiratory tract, skin and soft tissue infections implicated bacteria. S. Afr. J. Bot. 2018, 116, 116-122. [CrossRef]

5. Hossain, M.M. Therapeutic orchids: Traditional uses and recent advances-An overview. Fitoterapia 2011, 82, 102-140. [CrossRef]

6. Bhattacharyya, P.; Van Staden, J. Ansellia africana (Leopard orchid): A medicinal orchid species with untapped reserves of important biomolecules-A mini review. S. Afr. J. Bot. 2016, 106, 181-185. [CrossRef]

7. Gelfland, M.; Mavi, S.; Drummond, R.B.; Ndemera, B. The Traditional Medical Practitioner in Zimbabwe: His Principles of Practice and Pharmacopoeia; Mambo Press: Gweru, Zimbabwe, 1985; ISBN 086922350X.

8. Hutchings, A. Zulu Medicinal Plants: An Inventory; University of Natal Press: Pietermaritzburg, South Africa, 1996; ISBN 0869808931.

9. Bhattacharyya, P.; Kumar, V.; Van Staden, J. Assessment of genetic stability amongst micropropagated Ansellia africana, a vulnerable medicinal orchid species of Africa using SCoT markers. S. Afr. J. Bot. 2017, 108, 294-302. [CrossRef]

10. Baskaran, P.; Ncube, B.; Van Staden, J. In vitro propagation and secondary product production by Merwilla plumbea (Lindl.) Speta. Plant Growth Regul. 2012, 67, 235-245. [CrossRef]

11. Giri, L.; Dhyani, P.; Rawat, S.; Bhatt, I.D.; Nandi, S.K.; Rawal, R.S.; Pande, V. In vitro production of phenolic compounds and antioxidant activity in callus suspension cultures of Habenaria edgeworthii: A rare Himalayan medicinal orchid. Ind. Crops Prod. 2012, 39, 1-6. [CrossRef]

12. Bhattacharyya, P.; Kumar, V.; Grúz, J.; Doležal, K.; Van Staden, J. Deciphering the phenolic acid reserves and antioxidant activity within the protocorm like bodies of Ansellia africana: A vulnerable medicinal orchid. Ind. Crops Prod. 2019, 135, 21-29. [CrossRef]

13. Dixon, R.A.; Paiva, N.L. Stress-induced phenylpropanoid metabolism. Plant Cell 1995, 7, 1085. [CrossRef]

14. Rocha, L.D.; Monteiro, M.C.; Teodoro, A.J. Anticancer properties of hydroxycinnamic acids-A Review. Cancer Clin. Oncol. 2012, 1, 109-121. [CrossRef]

15. Chinsamy, M.; Finnie, J.F.; Van Staden, J. The ethnobotany of South African medicinal orchids. S. Afr. J. Bot. 2011, 77, 2-9. [CrossRef]

16. Lalthafamkimi, L.; Bhattacharyya, P.; Bhau, B.S.; Wann, S.B.; Banik, D. Direct organogenesis mediated improvised mass propagation of Pogostemon cablin: A natural reserve of pharmaceutical biomolecules. S. Afr. J. Bot. 2020. [CrossRef]

17. Larkin, P.J.; Scowcroft, W.R. Somaclonal variation-A novel source of variability from cell cultures for plant improvement. Theor. Appl. Genet. 1981, 60, 197-214. [CrossRef]

18. Sood, H.; Chauhan, R.S. Biosynthesis and accumulation of a medicinal compound, Picroside-I, in cultures of Picrorhiza kurroa Royle ex Benth. Plant Cell Tissue Organ Cult. 2010, 100, 113-117. [CrossRef]

19. Zielińska, S.; Piątczak, E.; Kalemba, D.; Matkowski, A. Influence of plant growth regulators on volatiles produced by in vitro grown shoots of Agastache rugosa (Fischer \& CA Meyer) O. Kuntze. Plant Cell Tissue Organ Cult. 2011, 107, $161-167$.

20. Tisserat, B.; Vaughn, S.F. Growth, morphogenesis, and essential oil production in Mentha spicata L. plantlets in vitro. Vitro Cell. Dev. Biol.-Plant 2008, 44, 40-50. [CrossRef]

21. Sudriá, C.; Pinol, M.T.; Palazón, J.; Cusidó, R.M.; Vila, R.; Morales, C.; Bonfill, M.; Canigueral, S. Influence of plant growth regulators on the growth and essential oil content of cultured Lavandula dentata plantlets. Plant Cell Tissue Organ Cult. 1999, 58, 177-184. [CrossRef]

22. Ali, H.; Khan, M.A.; Kayani, W.K.; Khan, T.; Khan, R.S. Thidiazuron regulated growth, secondary metabolism and essential oil profiles in shoot cultures of Ajuga bracteosa. Ind. Crops Prod. 2018, 121, 418-427. [CrossRef]

23. Erişen, S.; Kurt-Gür, G.; Servi, H. In vitro propagation of Salvia sclarea L. by meta-Topolin, and assessment of genetic stability and secondary metabolite profiling of micropropagated plants. Ind. Crops Prod. 2020, 157, 112892. [CrossRef]

24. Semnani, K.M.; Akbarzadeh, M.; Changizi, S. Essential oils composition of Stachys byzantina, S. inflata, S. lavandulifolia and S. laxa from Iran. Flavour Fragr. J. 2006, 21, 300-303. [CrossRef]

25. Öztürk, M.; Kolak, U.; Duru, M.E.; Harmandar, M. GC-MS analysis of the antioxidant active fractions of Micromeria juliana with anticholinesterase activity. Nat. Prod. Commun. 2009, 4, 1934578X0900400923. [CrossRef]

26. Umaru, I.J.; Badruddin, F.A.; Umaru, H.A. Phytochemical screening of essential oils and antibacterial activity and antioxidant properties of Barringtonia asiatica (L) leaf extract. Biochem. Res. Int. 2019, 2019, 7143989. [CrossRef]

27. Luczkiewicz, M.; Jesionek, A.; Kokotkiewicz, A.; Migas, P.; Mardarowicz, M.; Szreniawa-Sztajnert, A.; Zabiegala, B.; Bucinski, A. Production of essential oils from in vitro cultures of Caryopteris species and comparison of their concentrations with in vivo plants. Acta Physiol. Plant. 2015, 37, 58. [CrossRef]

28. Wang, L.; Jian, S.; Nan, P.; Liu, J.; Zhong, Y. Chemotypical variability of leaf oils in Elephantopus scaber from 12 locations in China. Chem. Nat. Compd. 2005, 41, 491-493. [CrossRef] 
29. Fragnière, C.; Aebischer, J.-N.; Dudler, V.; Sager, F. A short study on the formation of styrene in cinnamon. Mitteilungen Leb. Hyg. 2003, 94, 609-620.

30. Steele, D.H.; Thornburg, M.J.; Stanley, J.S.; Miller, R.R.; Brooke, R.; Cushman, J.R.; Cruzan, G. Determination of styrene in selected foods. J. Agric. Food Chem. 1994, 42, 1661-1665. [CrossRef]

31. Huo, X.; Gao, Y.; Yang, N.; Liu, W.; Liu, J. Chemical Composition of the Essential Oil of Herba taxilli. Biotechnology $2008,2$.

32. Fernandez, X.; Lizzani-Cuvelier, L.; Loiseau, A.; Perichet, C.; Delbecque, C.; Arnaudo, J. Chemical composition of the essential oils from Turkish and Honduras Styrax. Flavour Fragr. J. 2005, 20, 70-73. [CrossRef]

33. Faridi, P.; Ghasemi, Y.; Mohagheghzadeh, A. Chemical composition of Peganum harmala smoke and volatile oil. J. Essent. Oil Bear. Plants 2013, 16, 469-473. [CrossRef]

34. Sieniawska, E.; Baj, T.; Kowalski, R.; Skalicka-Wozniak, K.; Glowniak, K. Chemical composition and in vitro antioxidant activity of Mutellina purpurea Thell. flowers essential oil. Rec. Nat. Prod. 2014, 8, 203.

35. Yeon, B.; Sowndhararajan, K.; Jung, J.; Jhoo, J.; Kim, S. Comparison of Volatile Composition of Supercritical Carbon Dioxide Extract from Rhizomes of Korean Medicinal Plant 'Chun-Kung' (Cnidium Officinale Makino) by Direct-And SPME-GC/MS. Int. J. Pharm. Pharm. Sci. 2014, 6, 355-358.

36. Boik, J. Natural Compounds in Cancer Therapy; Oregon Medical Press: Princeton, MN, USA, 2001; ISBN 0964828014.

37. Kim, D.H.; Park, M.H.; Choi, Y.J.; Chung, K.W.; Park, C.H.; Jang, E.J.; An, H.J.; Yu, B.P.; Chung, H.Y. Molecular study of dietary heptadecane for the anti-inflammatory modulation of NF-kB in the aged kidney. PLoS ONE 2013, 8, e59316. [CrossRef]

38. Vats, S.; Gupta, T. Evaluation of bioactive compounds and antioxidant potential of hydroethanolic extract of Moringa oleifera Lam. from Rajasthan, India. Physiol. Mol. Biol. Plants 2017, 23, 239-248. [CrossRef]

39. Holmberg, B.; Malmfors, T. The cytotoxicity of some organic solvents. Environ. Res. 1974, 7, 183-192. [CrossRef]

40. Cruzan, G.; Carlson, G.P.; Johnson, K.A.; Andrews, L.S.; Banton, M.I.; Bevan, C.; Cushman, J.R. Styrene respiratory tract toxicity and mouse lung tumors are mediated by CYP2F-generated metabolites. Regul. Toxicol. Pharmacol. 2002, 35, 308-319. [CrossRef]

41. De Meester, C.; Poncelet, F.; Roberfroid, M.; Rondelet, J.; Mercier, M. Mutagenicity of styrene and styrene oxide. Mutat. Res. Mol. Mech. Mutagen. 1977, 56, 147-152. [CrossRef]

42. Grayson, M.H.; Gill, S.S. Effect of in vitro exposure to styrene, styrene oxide, and other structurally related compounds on murine cell-mediated immunity. Immunopharmacology 1986, 11, 165-173. [CrossRef]

43. Leavens, T.L.; Farris, G.M.; James, R.A.; Shah, R.; Wong, V.A.; Marshall, M.W.; Bond, J.A. Genotoxicity and cytotoxicity in male B6C3F1 mice following exposure to mixtures of 1, 3-butadiene and styrene. Environ. Mol. Mutagen. 1997, 29, 335-345. [CrossRef]

44. Brocca, A.; Virzì, G.M.; de Cal, M.; Cantaluppi, V.; Ronco, C. Cytotoxic effects of p-cresol in renal epithelial tubular cells. Blood Purif. 2013, 36, 219-225. [CrossRef]

45. Chang, M.C.; Chang, H.H.; Chan, C.P.; Yeung, S.Y.; Hsien, H.C.; Lin, B.R.; Yeh, C.Y.; Tseng, W.Y.; Tseng, S.K.; Jeng, J.-H. p-Cresol affects reactive oxygen species generation, cell cycle arrest, cytotoxicity and inflammation/atherosclerosis-related modulators production in endothelial cells and mononuclear cells. PLoS ONE 2014, 9, e114446. [CrossRef]

46. Murakami, Y.; Kawata, A.; Ito, S.; Katayama, T.; Fujisawa, S. Inhibitory effects of p-cresol and p-hydroxy anisole dimers on expression of the cyclooxygenase-2 gene and lipopolysaccharide-stimulated activation of nuclear factor-kB in RAW264. 7 Cells. Vivo 2014, 28, 719-725.

47. Shen, Y.; West, C.; Hutchins, S.R. In vitro cytotoxicity of aromatic aerobic biotransformation products in bluegill sunfish BF-2 cells. Ecotoxicol. Environ. Saf. 2000, 45, 27-32. [CrossRef] [PubMed]

48. Lu, X.; Yu, H.; Ma, Q.; Shen, S.; Das, U.N. Linoleic acid suppresses colorectal cancer cell growth by inducing oxidant stress and mitochondrial dysfunction. Lipids Health Dis. 2010, 9, 106. [CrossRef] [PubMed]

49. Shokoohinia, Y.; Bahrami, G.; Taherabadi, F.; Jaffari, F.; Hosseinzadeh, L. Apoptosis cell death effect of linoleic acid from Nigella sativa on human ovary cancer cells through mitochondrial intrinsic pathway. J. Rep. Pharm. Sci. 2018, 7, $20-26$.

50. Trimborn, M.; Iwig, M.; Glanz, D.; Gruner, M.; Glaesser, D. Linoleic acid cytotoxicity to bovine lens epithelial cells: Influence of albumin on linoleic acid uptake and cytotoxicity. Ophthalmic Res. 2000, 32, 87-93. [CrossRef] [PubMed]

51. MacLennan, M.; Ma, D.W.L. Role of dietary fatty acids in mammary gland development and breast cancer. Breast Cancer Res. 2010, 12, 211. [CrossRef]

52. Roy, S.; Rawat, A.K.; Sammi, S.R.; Devi, U.; Singh, M.; Gautam, S.; Yadav, R.K.; Rawat, J.K.; Singh, L.; Ansari, M.N. Alpha-linolenic acid stabilizes HIF-1 $\alpha$ and downregulates FASN to promote mitochondrial apoptosis for mammary gland chemoprevention. Oncotarget 2017, 8, 70049. [CrossRef]

53. Scheim, D.E. Cytotoxicity of unsaturated fatty acids in fresh human tumor explants: Concentration thresholds and implications for clinical efficacy. Lipids Health Dis. 2009, 8, 54. [CrossRef]

54. Botzki, A.; Rigden, D.J.; Braun, S.; Nukui, M.; Salmen, S.; Hoechstetter, J.; Bernhardt, G.; Dove, S.; Jedrzejas, M.J.; Buschauer, A. 1-Ascorbic Acid 6-Hexadecanoate, a potent hyaluronidase inhibitor X-ray structure and molecular modeling of enzyme-inhibitor complexes. J. Biol. Chem. 2004, 279, 45990-45997. [CrossRef]

55. Sethupathy, S.; Vigneshwari, L.; Valliammai, A.; Balamurugan, K.; Pandian, S.K. L-Ascorbyl 2,6-dipalmitate inhibits biofilm formation and virulence in methicillin-resistant Staphylococcus aureus and prevents triacylglyceride accumulation in Caenorhabditis elegans. RSC Adv. 2017, 7, 23392-23406. [CrossRef] 
56. Mushtaq, S.; Uzair, B.; Hameed, A.; Khayam, A.U.; Irum, S.; Shahzad, K.; Khan, B.A.; Ismail, M.; Ahmad, N.; Abbasi, R. In Vitro Cytotoxicity of Secondary Metabolites Extracted from Pseudomonas aeruginosa BS25 Strain. Arab. J. Sci. Eng. 2020, 45, 81-94. [CrossRef]

57. Begum, S.M.F.M.; Priya, S.; Sundararajan, R.; Hemalatha, S. Novel anticancerous compounds from Sargassum wightii: In silico and in vitro approaches to test the antiproliferative efficacy. J. Adv. Pharm. Educ. Res. 2017, 7, $273-277$.

58. Orrenius, S.; Nicotera, P.; Zhivotovsky, B. Cell death mechanisms and their implications in toxicology. Toxicol. Sci. 2011, 119, 3-19. [CrossRef]

59. Bakkali, F.; Averbeck, S.; Averbeck, D.; Idaomar, M. Biological effects of essential oils-A review. Food Chem. Toxicol. 2008, 46, 446-475. [CrossRef]

60. Doležal, K.; Popa, I.; Kryštof, V.; Spíchal, L.; Fojtíková, M.; Holub, J.; Lenobel, R.; Schmülling, T.; Strnad, M. Preparation and biological activity of 6-benzylaminopurine derivatives in plants and human cancer cells. Bioorg. Med. Chem. 2006, 14, 875-884. [CrossRef]

61. Doležal, K.; Popa, I.; Hauserová, E.; Spíchal, L.; Chakrabarty, K.; Novák, O.; Kryštof, V.; Voller, J.; Holub, J.; Strnad, M. Preparation, biological activity and endogenous occurrence of N6-benzyladenosines. Bioorg. Med. Chem. 2007, 15, 3737-3747. [CrossRef]

62. Murashige, T.; Skoog, F. A revised medium for rapid growth and bio assays with tobacco tissue cultures. Physiol. Plant. 1962, 15, 473-497. [CrossRef]

63. Vasudevan, R.; Van Staden, J. In vitro asymbiotic seed germination and seedling growth of Ansellia africana Lindl. Sci. Hortic. 2010, 123, 496-504. [CrossRef]

64. Mosmann, T. Rapid colorimetric assay for cellular growth and survival: Application to proliferation and cytotoxicity assays. J. Immunol. Methods 1983, 65, 55-63. [CrossRef]

65. Omokhua, A.G.; McGaw, L.J.; Chukwujekwu, J.C.; Finnie, J.F.; Van Staden, J. A comparison of the antimicrobial activity and in vitro toxicity of a medicinally useful biotype of invasive Chromolaena odorata (Asteraceae) with a biotype not used in traditional medicine. S. Afr. J. Bot. 2017, 108, 200-208. [CrossRef]

66. Rubinstein, L.V.; Shoemaker, R.H.; Paull, K.D.; Simon, R.M.; Tosini, S.; Skehan, P.; Scudiero, D.A.; Monks, A.; Boyd, M.R. Comparison of in vitro anticancer-drug-screening data generated with a tetrazolium assay versus a protein assay against a diverse panel of human tumor cell lines. J. Natl. Cancer Inst. 1990, 82, 1113-1118. [CrossRef] [PubMed] 